\title{
The Relationship Between Father and Child in Daily Life Narratives of Female Academicians with Children in Pre-School Period
}

\author{
Esra Gedik **
}

\begin{abstract}
In Turkey, family and society are subjected to the process of social transformation in every area in which they are constructed. When the family structure in Turkey is examined, the traditional large families, nuclear families, small and single-parent families can be observed. When the family structure changes to the nuclear family, responsibilities in the family have started to change as well. In particular, as the role of and the need toward mothers increased in working life, although they used to be the only one interested in the child in the past, now fathers have begun to concern themselves with their children and education better. Therefore, this study analyzed the father-child relationship in the daily life narratives of working women academicians. In this regard, 15 women, who were working in Yozgat, were interviewed indepth. The sociological perspective evaluates father/fatherhood in related with masculinity rather than being biologically male. The fatherhood is influenced by the social structure and forms the structure of the society with the meanings attributed to fatherhood. In this sense, this study examined the paternity perception of the spouses of the interviewed women from the perspective of women within the context of "involved fatherhood" literature. In this sense, the study showed that the perception of the father-child relationship by women academicians is structured within the framework of traditional gender roles attributed to men and women in Turkish society. It was seen in the narratives of women with higher education, such as academic education, had very limited effects on their husbands' perception of fatherhood in their family lives and that fathers were affected by both the conservative structure of their own families and the perception of masculinity in the society.
\end{abstract}

Keywords: Fatherhood, masculinity, father-child relationship, women academicians, Yozgat.

\footnotetext{
* Received:07/01/2020 - Accepted: 28/02/2020

** Yozgat Bozok University Faculty of Science and Literature Department of Sociology.

Orcid id: 0000-0003-3192-2107,esra.gedik@bozok.edu.tr
} 


\title{
Okul Öncesi Dönemde Çocuğu Olan Kadın
}

\section{Akademisyenlerin Günlük Yaşam Anlatılarında Baba- Çocuk Iilşkisi*}

\author{
Esra Gedik**
}

\section{Öz}

Türkiye'de ailenin de toplumun her alanda görülen değişiminden etkilendiği bir gerçektir. Türkiye'deki aile yapısı incelendiğinde, geleneksel büyük aileler, çekirdek aileler, küçük ve tek ebeveynli aileler görülebilir. Aile yapısı değiştikçe aile içindeki rol dağılımı ve sorumlulukları da değişmiştir. Özellikle annenin çalışma hayatındaki yeri ve annelerin çalışma hayatına gereksinimi arttıkça, çocukla tek ilgilenen anne iken, babalar da çocuklarıyla daha fazla ilgilenmeye, çocuk bakımından eğitimine kadar pek sürece daha fazla önem vermeye başlamıştır. Bu nedenle bu çalışma, çalışmakta olan kadın akademisyenlerin günlük yaşam anlatılarında baba-çocuk ilişkisini analiz etmiştir. Bu kapsamda Yozgat'ta çalışan 15 akademisyen kadınla derinlemesine görüşme yapılmıştır. Sosyolojik perspektif babalığı biyolojik olarak erkek olmakla ilgili analiz etmek yerine, toplumdaki erkeklik algılarıyla ilgili analiz eder. Babalık toplumsal yapıdan etkilenerek toplumun baba olmaya yüklendiği anlamlarla şekillenir. Bu çalışma Türkiye'de yeni çalışılmaya başlanılan “ilgili babalık” literatürü kapsamında, görüşülen kadınların eşlerinin babalık algısını kadınların perspektifinden incelemiştir. Çalışma göstermiştir ki kadın akademisyenlerin baba-çocuk algısı Türkiye toplumunda kadına ve erkeğe atfedilen geleneksel toplumsal cinsiyet rolleri çerçevesinde yapılanmaktadır. Akademisyen annelerin anlatımlarında, akademik eğitim gibi yüksek eğitime sahip olan kadınların aile yaşamlarında eşlerinin babalık algısına etkilerinin çok sınırlı kaldığı ve babaların hem kendi ailelerinin muhafazakâr yapısından hem de toplumdaki erkeklik algısından etkilendikleri görülmüştür.

Anahtar Sözcükler: Babalık, erkeklik, baba-çocuk ilişkisi, kadın akademisyenler, Yozgat.

\footnotetext{
* Geliş tarihi:07/01/2020 • Kabul tarihi: 28/02/2020

* Yozgat Bozok Üniversitesi Fen-Edebiyat Fakültesi Sosyoloji Bölümü.

Orcid no: 0000-0003-3192-2107, esra.gedik@bozok.edu.tr
} 


\section{The Relationship Between Father and Child in Daily Life Narratives of Female Academicians with Children in Pre- School Period}

In terms of relationships with children, the family is an institution that influences the child from the prenatal period until death. Today, studies suggest that the knowledge, behaviors and attitudes emerging from the mother-father-child interaction in the early years of the child's life continue to be influential in their life also in the years ahead (Özdal and Aral, 2005: 256). Children learn first from family. Social learning at home is more influential than all the teachers to teach the child in the future. Since, in the early stages of childhood, individuals learn through observation and imitation, communication with parents offers numerous opportunities to children's life (Gürşimşek, 2002: 25-43; Zeybekoğlu, 2013). Being a mother or a father is not a "natural" status or a role but a social construct (Bayraktar 2011; Bora and Üstün 2005; Sancar 2009). Thus, mothers and fathers, as parents that can be shaped by the society may assume traditional forms. According to structural functionalist approach, mothers are assigned expressive roles i.e. social tasks, whereas fathers are assigned instrumental roles, i.e. fulfilling the material needs of the family. Mother, is depicted as the one who organizes housework, childcare and the family's emotional life (Zeybekoğlu et al. 2011: 25-34).

It is a fact that family in Turkey is subjected to social change, a process experienced by societies in every domain. As a consequence of industrialization, and thus the urbanization process starting with rural flight, family structure in Turkey evolved from traditional large families to nucleus families, and today even to singleparent families. In these family structures, domestic relationships have also experienced a transformation. As more and more women, including those with children, have started to participate in the labor market, they are no longer the only ones who are assigned the responsibility for childcare; instead, fathers have increasingly become more involved with their children (Güngörmüş, 2001: 245). With respect to child development and care, fatherhood is one of the most critical factors along with motherhood. In their study carried out for the "involved fatherhood" (Ilgili 
Babalık) project by AÇEV (Mother Child Education Foundation), Ulaş Uğraş Tol and Demet Taşkan stated that "fathers (although, still a very limited number of them) have become more involved in housework compared to past and even more involved in childcare and child-rearing to a certain extent." (2018: 10) It has been observed that, although mothers are considered to have the primary role in basic care and education of children, fathers have started to depart from the role of being the one who solely generates income and become more active in their child's development and education (Çağdaş, 2011).

A society's concept of a father and men's fatherhood practices are shaped and produced by the relationship ties the individual is in. In this regard, this study explores the relationship between father/fatherhood and child in daily life narratives of female academicians with children in the pre-school period. For this purpose, I focused on the narratives of women as women's personal narratives provide an ideal starting point for studying the interaction between the individual and society in the construction of gender. Moreover, according to Anıl Biray Birer (2019: 13) "Narratives of women in feminist perspective are particularly important because women's conditions in their lives and the subjective meanings they attach to events are manifested in women's narratives; so social and cultural processes have new meaning for researchers." This study also endeavors to find out the elements that shape the father figure constructed by mothers and, as a result of that, whether women with a high level of education move away from the traditional father/fatherhood perception.

The reason why I look at the conception of father/fatherhood in the narratives of women is that masculinity and masculine domination is not just a process that men establish on women and other men, but also it is reproduced by women in society. It is the main purpose of the research to determine how mothers shape fatherhood, a social construction. The mother acts like a catalyst in the father-child relationship (Krampe, 2009: 875). A study carried out by Richard Atkins (1981) similarly suggests that children's and the fathers' father perception is shaped by mothers. That's why, the main reason for interviewing with women academicians in particular, is to understand how the images of father which stand out in the narratives of these women, take shape with the motivation that scientists can view their society more critically. The perception of the fatherhood of women living in a socio-economically developed urban area, 
whose education level is relatively high, with a high tendency to work, with a low number of children and with relatively high-income families is wondered.

\section{Role of Fatherhood}

Robert Connell and James Messerschmidt (2005) claim that multiple forms of masculinity exist in a society, but one form of masculinity is dominant such as being strong, successful, capable, unemotional, and in control. Understandings of masculinity and fathering in contemporary sociology are important. Fatherhood and masculinity highlight the cultural and ideological constructions of the given society. What is considered "good" fathering can change over time in response to the change in hegemonic masculinity. Fatherhood cannot be understood separate from masculinity: to study fathers is to study masculinity.

The norm of the father as breadwinner can be viewed as hegemonic. Hegemonic masculinity informs fathering because it defines what fathers are expected to be and what a good father should be. Hegemonic forms of masculinity constructed the fathering as an authoritarian, disinterested, financial provider, and emotionally distant (Ammari and Schoenebeck, 2015). Being a father is one of the most difficult ways to understand being a man. Being a father for a man is not as concrete as a woman's connection to "being a mother by giving birth." In this respect, it is also connected with the understanding of hegemonic masculinity in society. As emphasized in researches about becoming a man in Turkey, being a father is a part of masculinity (Sancar, 2009). It is in the direction that fathers' masculinity values are also passed on to their children as a "role model". Serpil Sancar (2009) states that different paternity models correspond to different masculinity models. According to Sancar (2009), different masculinity and father models are primarily related to cultural capital based on education and family forms that make up the rural-urban distinction and class differences. However, many studies (Hunter, et all, 2017; Brandth and Kvande, 2018; Petts, et all. 2018) point out that changing fathers remain connected to hegemonic masculine norms in society as this study emphasized in the following part.

Fatherhood has remained a neglected issue for a long time both in the academic and cultural discourse in contrast with extensive attention on motherhood. Hence, as more mothers went outside their house, the roles of fathers in the lives of their children 
were begun to be questioned (Craig, 2006). They are expected to share child-care duties. This study examines the alterations in the cultural images of fatherhood identities and actual behaviors.

The recent researches mentioned that relationships with parents in the preschool period are of great importance for the children in the age-group 0-6 years (Knauth, 2000: 496-509). The child needs their father's presence just as they need their mother's attention and protection. To speak of fathers, how fatherhood is defined should be the primary question. According to Kerry Daly (1993: 513), fatherhood reflects the context one lives in and as the context changes, fatherhood may change too. In today's societies in which social change frequently takes place, roles associated with motherhood and fatherhood are also subject to change. The role of fatherhood emerged in different ways in different cultures. Thus, neither fatherhood nor the states of masculinity cannot be stable, they change (Morgan, 2001), for instance, traditional married father, single father, homosexual father, etc. Therefore, it is hard to come up with a fixed definition of fatherhood.

In some societies, fatherhood may label men (for example, the father who cannot have a son). Men's perceptions of fatherhood are affected by such factors as their education, profession, economic conditions, family structure, age, and how many children they have (Telli and Özkan, 2014). Margaret Mead (As cited in Mercan and Şahin, 2017: 5) suggests that the role of fatherhood is associated with various factors depending on the culture, and says that sometimes fatherhood is identified as being playmates while sometimes the unit authority. A traditional definition of fatherhood considers the father to be the person who shoulders several responsibilities such as generating income for the family and disciplining the children (Mintz, 1998). The expression of "traditional fatherhood" has been generally used to describe noninvolved paternal issues and they also have minimal physical and emotional availability for children (Freeman, 2008). In this sense, the role of the father is limited by economic support and discipline. In terms of father-child relationships, traditional fathers were mostly involved in guiding, educating and disciplining their children. There is a lack of father involvement in childcare which was accepted as the role of mothers. Fathers who are assigned traditional father role not only allocate little time for their children but also undertake childcare less. To them, childcare is limited by providing monetary 
support and practicing discipline. Since they support their families economically they perceive themselves as active and responsible (Feldman et al., 1983: 1628). In the traditional society, children used to be brought up scared, intimidated, and, as required, beaten and their curiosity and free acts were restrained. When they act up they were intimidated with father, while fathers were not on familiar terms with children and avoided demonstrating their love (Yörükoğlu, 1992). Traditional fathering can be seen as a reflection of hegemonic masculinity characteristics in the family. These can be summarized as breadwinning, ensuring for his family a safe and protective environment, maintaining discipline and control, being a model for his children and being a representative figure of his family in the society.

The concept of fatherhood is also affected by the rapid changes in the world (Güngörmüş-Özkardeş, 2010, 19). As Alan Booth and Ann Crouter (1998) states, men's domestic role as fathers undergoes some changes in time due to economic changes and major historical events. In this period when the public-private division emerged after the industrial revolution, fatherhood evolved into the role of "breadwinner" and was associated with the public sphere. In many studies, historical development of fatherhood is explained at four stages as follows: At the first stage, fathers were defined as "moral teachers". In the second stage, they were considered "means of livelihood" between the 18th and 20th centuries. They were classified as the "role model" between the 40s and 60s. At the final stage, they have become a subject of discussion with the model of involved father (Lamp, 1998; Mintz, 1998, Booth and Crouter, 1998).

The 1970s formed the basis of the new father image. With the 1970s, fathers were observed to actively participate in their children's care. The "crisis of breadwinner father" has been referred to much as of the 1970s (Gillis, 2000). Others prefer saying "fatherhood in transition" referring to fatherhood in this period (Bjornberg, 1992). "New father" is related with the task of fulfilling the duty of bringing home income as well as participating in childcare, playing with them, shopping together, going to the game and new father is expected to develop emotional relationships with his children (Çubuklu 2007, 105-106). Umut Beşpınar explains the change in the new fatherhood as follows: The increase in the participation of women in business life, the development of awareness of the effect of the father's role on the child, the change in gender roles 
from the hierarchical model to an egalitarian model, and the transformation and illegitimate of hegemonic masculinity (2015: 98). The worsening of the economic conditions, the increase of the education levels of women and the technological developments increase the need for the female workforce every day, the mother's entering the working life causes changes in the duties and responsibilities of the father in the family.

Today, fatherhood appears as a socially constructed role. Since now women's performance of motherhood along with their non-domestic jobs has become socially acceptable as a result of the transformation of the domestic division of labor led by industrialization and urbanization, a new role of fatherhood has emerged which is rooted in today's values rather than a fatherhood model that is rooted in the past. In post-industrial societies, men and women become equal in terms of work, education, and social and political participation. Family institution turns to redistribution of roles based on women's demands for equality. The domestic role of women gets reconstructed in line with the principle of having equal rights with men. As a result, the transition from the traditional fatherhood to the process we call "new fatherhood" commences. In terms of male parenting, involvement in the lives of children ${ }^{1}$ is the most defining aspect of new fatherhood. The new father attends his child's delivery, looks after them also in babyhood, does not content himself with playing, participates in childcare more actively and cares about his daughter as much as his son. The nascent role of fathers is a mixture of the role of mothers and the traditional role of fathers (Harris and Morgan, 1991:531-544).

That now men are leaning towards the egalitarian approach rather than the traditional approach of the division of labor and are more involved in childcare compared to the past gave rise to this definition. Thus, in addition to motherhood, studies on fatherhood and the figure of father gained momentum.

In addition to the concepts of "fatherhood" and "the new fatherhood" that are accounted for by social change, there are approaches addressing fatherhood by way of a dual distinction. Ralph LaRossa is one of the first to make this dual distinction. He asserted that the fatherhood institution divides into two: the culture of fatherhood and

\footnotetext{
1 These can be summarized as being physically available at home; participating in childcare duties and sharing same amount of work with wives; maintaining communication with the children; being affectionate, loving and approachable (Shirani and Henwood, 2011).
} 
the conduct of fatherhood. Accordingly, he defined the culture of fatherhood as the shared norms, values and beliefs whereas the conduct of fatherhood as what fathers actually do, in other words, behaviors of the father (LaRossa, 1988: 451-457). There are many other studies that speak of this distinction. What those studies share in common is the fact that the change in the culture is fast; however, the conduct cannot keep pace with it (Levant, 1990; Daly, 1993; LaRossa, 2007). Each period has its culture of fatherhood that is renewed with respect to its own prominent cultural values. On the other hand, the uncertainty about how other members of the society will react to, in other words, the concern about "what others will say" about the new conduct of fatherhood may be influential on why it falls behind. The codes of masculinity emerging around the patriarchal relationships that fathers adopt and are influenced by are one of the most significant factors that construct how men father (Coltrane, 2010). In other words, fathers are stuck between the "new fatherhood" and the "traditional fatherhood". Carla Shows and Naomi Gerstel (2009) compared the paternal attitudes of working and middle-class men. They used two phrases for exposing the paternal differences between these groups; "public" and "private" fathering. Middle-class fathers showed patterns of public fathering which is similar to LaRossa's (1988: 380) description of "technically present but functionally absent fathers". Accordingly, most of these fathers were aware of the cultural norms of new fathering yet the responsibility of breadwinning in their mind conflicted with these norms. This study also reveals the results of Shows and Gerstel's (2009) study which we can see the division of public and private fathering in the narratives of mothers. Men totally behaved in accordance with traditional fatherhood norms without any doubts or guilt related to their absence in childcare. Yet they still intended to be more egalitarian in their fatherhood.

Although fatherhood has changed from past to today, this change is often related to the culture of fatherhood rather than the conduct of fatherhood. Today, involved fathers push pushchairs, change diapers, and come to the playgrounds. However, according to Glenda Wall and Stephanie Arnold (2008), despite the change, fathers are still considered the secondary parent. In this sense, studies revealed that the father-child relationship differs from the mother-child relationship in terms of both quality and quantity. Fatherhood starts with pregnancy and persists throughout one's life. According to Asena Telli and Hava Özkan (2014), the father plays a critical part in 
the first five years of a child's life in that children's personality is shaped between the ages of $0-6$. In this period, the father undertakes his responsibilities while also contributing not only to himself but also to the healthy development of his child. It is apparent from the father-child relationship in today's family structures that the father figure is influential in many aspects, especially in the development of intelligence, personality, and sex of the child. Studies revealed that children's mental, emotional, gender identity and social development is affected positively in children's socialization process when fathers take an active role in childcare and spend more time with their child(ren) engaging in physical activities, plays, etc. (Kuzucu, 2011: 82-84).

Turkey has undergone large scale transformation especially in the second half of the last century. Expectedly, these transformations have crucial effects on the traditional structure of the family. In Turkey; few studies focus on the father-child relationship and fatherhood (Güngörmüş-Özkardeş, 2010: 24; AÇEV reports 2018). Sancar (2009) studied both the private and public masculinity positions in Turkey. Providing for a family was documented as the most prevailing aspect of fatherhood in Turkey. The traditional father role is among the fatherhood descriptions that are approved by the society in Turkey. Similarly, in her study, Beşpınar (2015: 849) mentioned that there is a distinction between the ideals and practices of fatherhood in Turkey. The course of history suggests that in Turkey, fathers have been considered responsible for livelihood rather than child-rearing. It is the father who provides for the family, imposes strict discipline and is sometimes a playmate. Changing gender norms and the increasing numbers of women in the workforce in Turkey also create pressure for men to share more equitably in domestic and childcare responsibilities.

\section{The Impact of Father on the Socialization Process}

Fathers occupy a critical place in the daughter's lives. What fathers do, what they say, their relationship with the mother, their attitudes and behaviors toward women lay the foundation of the communication and affair the girls are to establish with men in the future. Father represents the outer world, power, and authority (Karaköse and Karaköse, 2007: 45-76).

A study conducted in Turkey (İmamoğlu, 1991) highlights gender-related differences in domestic relationships. Mentioned study stressed the importance of the 
relationship between the youth and mothers and revealed that mothers' relationship with both genders is intense whereas fathers are closer with their sons compared to their daughters (As cited in Tezel et al., 2007: 784). The presence of fathers is of great importance not only to the boys but also to the girls. Girls, especially in preadolescence, look for signs that will make them feel loved by their fathers and the presence of fathers plays a part in strengthening the self-confidence and sexual identity of girls. Fathers' taking care of their daughters and showing their affection help them develop healthy relationships with both girls and boys in adolescence (Cited in Özdal and Aral, 2005: 256)

Identification with father has a vital role in boys' identity development. As cited in Funda Özdal and Neriman Aral (2005: 256), studies reveal that father is important in especially boys' acquisition of masculine behaviors. Boys learn how to act like a man by identifying with their fathers. Studies also put forward that fathers are more involved with their daughters' rather than sons' safety, treat their sons in a stricter and more controlled manner compared to they do with their daughters, and contribute to their sons' motor development more than they do to that of their daughters (Özdal and Aral, 2005: 256). The increasing attention paid by the father to the child affects the child's, whether a boy or a girl, sociable behaviors and ability for empathy positively. Therefore, the social and emotional development of child improves (Erdoğan, 2004: 147-153).

On the other hand, cultural structure and norms define men's father position. Thus, feminist studies put more emphasis on fatherhood. They assert that attentive and involved fathers will change not only the life of daughters but also the life of women. This is the motive behind this study.

\section{In-depth Interviews with Women Academicians}

This study focuses on father-child relationships in daily narratives of mothers from their perspective. In this study, the method of interview, a widely used qualitative research technique, is adopted (Donato et al., 2006). The first reason for this preference is that this method allows research that does not limit or homogenize women's experiences (Ramazanoğlu and Holland, 2002: 154-155). Second, it helps empathize with women and creates a fairer environment fully aware of the power relations in the process of 
information production. Third, this method is considered a research technique that is key to understanding the experiences of women and the contexts that give rise to these experiences (DeVault and Gross, 2012). So my questions were semi-structured and open-ended. Mostly listening to women's answers and how they established themselves, without interfering, I tried to understand how they make sense of their experience. When I share the results, I chose to deliver what women told during interviews because, as John W. Creswell (2007) states, making quotations from interviewees is the best way of showing the results and giving voice to participants.

In addition to in-depth interviews, survey notes taken during data collection are included in the study. The families are reached through snowball sampling, a type of sampling in which the study is commenced with a sample event in a network, and then the researcher, based on information on relevant relationships obtained from that event, identifies other sample events and repeats the process.

The population of the study is made up of female academicians with children in the pre-school period. The main reason for interviewing academician women for this study is to understand whether a parenting relationship, which is based on gender equality, is free from sexism, increases as the level of education increases. The study was carried out at a day nursery and in-depth interviews were made with 15 mothers who have children in the pre-school period (aged 48-60 months) and benefit from nursery education. The study is limited to 15 women. Although the results of the indepth interviews cannot be generalized, this method can be done with a limited number of people due to nature, but the field information obtained in the in-depth interviews offers very rich information for communities with a similar profile. The demographic profiles of the mothers can be seen Table 1 as follows.

\begin{tabular}{|l|l|l|l|}
\hline $\begin{array}{l}\text { Interviewed } \\
\text { Mothers }\end{array}$ & $\begin{array}{l}\text { Education } \\
\text { Status }\end{array}$ & Age & $\begin{array}{l}\text { Number of } \\
\text { Children }\end{array}$ \\
\hline $\mathrm{X}$ & Master & 28 & 2 \\
\hline $\mathrm{Y}$ & Ph.D. & 33 & 1 \\
\hline $\mathrm{Z}$ & Ph.D. & 35 & 1 \\
\hline $\mathrm{K}$ & Ph.D. & 36 & 3 \\
\hline $\mathrm{L}$ & Master & 29 & 2 \\
\hline $\mathrm{M}$ & Ph.D. & 38 & 1 \\
\hline $\mathrm{N}$ & Master & 27 & 1 \\
\hline $\mathrm{P}$ & Master & 29 & 2 \\
\hline
\end{tabular}




\begin{tabular}{|l|l|l|l|}
\hline R & Ph.D. & 35 & 1 \\
\hline S & Ph.D. & 34 & 2 \\
\hline S & Master & 27 & 1 \\
\hline A & Ph.D. & 37 & 2 \\
\hline T & Master & 28 & 1 \\
\hline D & Master & 33 & 2 \\
\hline W & Ph.D. & 42 & 2 \\
\hline
\end{tabular}

Table 1: Information on the Interviewed Mothers

This study adopts the method of "descriptive analysis" for data analysis. A descriptive study puts forth the absence or the presence of a relation. Aimed only at describing, this type of study does not explain the cause of or reason to the situation. Interview questions were arranged in the light of information obtained from the literature research made before the interviews and earlier research. The texts of answers, including direct observation notes, were evaluated under main headings and elaborated on in the ongoing parts.

\section{From Hegemonic Masculinities to New Fathers: The Main Points from Women's Narratives on Father-Child Relationship}

Three main themes emerged from the interviews which will be emphasized in this chapter. One of the themes is about the structure of the fathers' own families which affect how to be a father even if women academicians try to equalize the domestic chores. Second theme is how the hegemonic masculinities are constructed in the narratives of women. Final theme is about whether we can talk about new fatherhood or not in the narratives of women.

\section{The Structure of the Fathers' Families}

When the division of labor in families between mothers and fathers is discussed, it is necessary to take into account the possibility of conflicting needs and interests of the family members. The women I interviewed were married to men who mostly came from families having intense patriarchal dominance relationships and apparent gender division of labor. In the interviews, the majority of women stated that their husbands 
adopt more traditional approaches and attitudes in child-rearing and daily life due to the traditional structure of their families.

...My husband's family believes that men should do nothing at home. When they see my husband help me with childcare and daily housework they say "Son, a man shouldn't be doing this" or to me "If not today, you can do it tomorrow", but I managed to lower the frequency of such statements saying that we live together and that's why we share everything. Of course, it was quite difficult to get my husband ready for this process. (Y, 33, Ph.D.) Since women in my husband's family do not work, he and his family experience for the first time such a situation where a woman is not a housewife. When we come home together in the evening or in terms of childcare we established a division of labor unintentionally, in the natural course of events. (L, 29, Master)

Some of the women I interviewed told that when their husbands separated from their own families to build a new one, they established an equal relationship with their wife, in general, constructing their fatherhood roles and they act on joint decisions in terms of household labor:

Our families do not interfere with how we raise our kids. Mothers interfere when it comes to what children should eat and drink but no one has said anything about my husband's relationship with the kid. He said he wanted to play a part in our kid's life. Since we both work, we do things in turn. Sometimes he feeds the kid, I work; sometimes I play with the kid, he goes to a meeting and such. (D, 33, Master)

Earlier studies in the field suggest that whether the mother works outside is an important determinant in the division of labor between partners (Zeybekoğlu, 2013, 320). Similarly, participants stated that their working plays a significant part in the division of household labor. The women I interviewed frequently said "done by whoever is available" when talking about fathers' contribution to the domestic division of labor. As a result, as the level of education increases, fathers realize that they should be more active in their children's lives, but they cannot implement it for various reasons.

On the other hand, although the female academicians said they try to establish a father-child relationship based on what is right, there happen to be obstacles to this purpose, such as the traditional character of the father's family or the father himself. For example, K (35, Ph.D.) narrates her husband's father-child relationship as follows: 


\begin{abstract}
Although we are both academicians, when my husband enters the home he, as a father, maintains the traditional family structure he inherited from his family. I haven't managed to get him to accept that fathers can change diapers or feed the baby. And when he does, we start over if his family comes up with even a shadow of criticism or a joke about these habits.
\end{abstract}

The father's male breadwinner ideology is also significant for the likelihood of his fathering in those families. Five of the women ${ }^{2}$ in this study pointed out that their husbands' mothers consider that the mother should be primarily responsible for childcare and the father should be primarily responsible for breadwinning. In families, although the mother has a higher occupational position in theory, child chores are more likely to be taken also by the mothers.

As we can understand from the narratives of the women, the division of labor and power in the home is pretty much related to men's families. Especially cultural conceptions of fatherhood in the families of fathers are important in relation to possibilities of doing fatherhood: if childcare is seen as the mother's responsibility, it is not easy for men to childcare because of conceptions of gendered parental responsibilities in their own family life.

\title{
Hegemonic Masculinity in Women's Narratives
}

Gender implies "the status, roles, duties and responsibilities in a society which men and women are a part of as individuals" and means "society's point of view, perceptions and expectations of individuals" (Sancar et. al. 2006: 13). Gender is presented to children in many ways from a very early age. Parents have a significant role in the early years of a child's life. A healthy child-parent relationship in the pre-school period lays the foundation of a child's personality development, the upcoming stages of their life and their adulthood. Aware of the importance of the pre-school period, almost all of the mother academicians who were interviewed in this study ensured that their husbands are actively involved in their children's socialization process,

...I believe father's attitudes are of importance especially with respect to our child's age range. Rather than trying to make up the deficiencies or our

\footnotetext{
2 These are: R, 35, Ph.D.; K, 35, PH.D.; D, 33, Master; L, 29, Master and Y, 33, PH.D.
} 
mistakes, we want to pursue a healthy process so my husband and I collaborate in every matter. (Z, 35, Ph.D.)

Before the fieldwork, I was thinking that highly educated women may have deliberately chosen a partner who is pro-sharing and can be expected to support her career by taking his share of childcare. However, the results of the narratives show us that compared to mothers, fathers with traditional mentality are less involved in childcarerelated duties. The traditional approach dictates that the mother plays a significant role in childcare, whereas father in kid's socialization. Female academicians also stated that they need their partner's active participation in their child's emotional, behavioral and cognitive development process rather than childcare. For example, a female academician said "We are fostering a boy. He should learn how to be a man. I can't teach this to him. My husband needs to show him to be a man. He should be a role model." (W, 42, Ph.D.)

They said that they do not demand the division of labor for childcare because they do not think men are as devoted and capable as women. Narratives of mothers can be seen both as a consequence and as part of gender discourse that reproduces it. Sevi Bayraktar (2011: 104) puts forth that a house is defined as the mother's area of responsibility and the obligation to arrange domestic relationships is given to the mother. The following narrative of S. can be proof of the Bayraktar's study:

...My husband has hardship in falling asleep and waking up, so I do not get him involved in the night phase. He is not so well in feeding, dressing and such either. However, I see his great contribution to our son's socialization by going to the park together, playing together, somehow including him in the activities he attends and I like it so much. (S, 34, Ph.D.)

Some of the mothers I interviewed pointed out that although men are involved in every aspect of childcare, they still have troubles because the society and families have a contrary perception. The women stated that they were being criticized for their husbands' childcare because the women did not have enough time for their children as they were working and that they could not be "the acceptable" mother. They stated that their husbands were mocked as "light man" (as used in a popular TV serial called Çocuklar Duymasın). Because of these regiments, many women stated that they directed their husbands mostly for the socialization of the children, especially boys, in 
order for their sons to be man, for their fathers to be role models and to be seen as more masculine.

When mothers are asked "who is father," their common answer was like T.'s answer: "Father is trust, the one who acquaint children with the world." "I feel strong when my husband supports me. Maybe he is not involved in childcare because of work but his presence is more than enough" (T., 28, Master). Most of the participant mothers used certain expressions in describing the father, for example, one who is trusted, one who protects, and the breadwinner. It is striking that we see in mothers' narratives such hegemonic masculinity discourses as power and breadwinner as the father description. Here, fathers are defined in mothers' narratives not in terms of their children but in terms of their masculine identity. According to the hegemonic masculinity perception, masculinity affects both other men who are not accepted as man and women. This masculinity dominates woman. Moreover, as can be seen from the narratives, this perception of masculinity is reproduced not only by men in society but also by women.

\section{New Father/Fatherhood}

According to Gönül Demez (2005: 135), in the traditional society in Turkey which is marked with the dominance of traditional large family, children could not smoke before their fathers, they stood up as a sign of respect, no one could kiss, caress or play with children before the father. However, the "new father" approach we mentioned above is visible in the narratives of female academicians. The transition from the traditional large family structure, in which the concept of the traditional father is dominant, to the nucleus family has led to a change in the concept of fatherhood. "New father" is more attentive, shows his love for his children and helps ${ }^{3}$ his wife with housework. When mothers request, fathers sometimes support them in housework and childcare. This study presents findings that are supportive of Özge Zeybekoğlu's (2013: 309) argument that:

\footnotetext{
${ }^{3}$ Here I have to emphasize a distinction. There is a difference between helping and sharing. The fact that men help women with housework may not mean that their gender roles have changed. In another sense, gender equality may not be considered as achieved. For example, the woman prepares three meals at home, while her husband helps her with making a salad. On the other hand, sharing household chores means that partners are equally share the chores. Therefore, this distinction shows us although the structure of fatherhood changes, culturally fatherhood can remain the same.
} 
Father, who has been the moral teacher in the period covering the 18th century and early part of the 19th century, transformed into breadwinner in the midst of Industrial Revolution. Although the two duties of today's fathers still remain, they have begun to play a more active role in the care and education of the child.

On the other hand, there is no discourse of criticism brought by the mothers against the fact that household work is primarily their responsibility and that there is no equitable distribution of labor between them and their husbands. Mothers who undertake the majority of housework consider themselves solely responsible for the house. In this sense, when mothers were asked what they expect of their husbands as a father they responded as follows: "Their helping mothers when necessary, supporting children in social life, being playmates with children, etc."

How much fathers attach importance to their child's gender in their relationship with their children is of particular importance for this study. However, mothers stated that they care about particularly the relationship between their sons. They gave importance to this points as they think that father-son relationship is important for boys' gender identity development. What M. (38, Ph.D.) says about this issue is a good example of this: "Since he is a boy, he rather identifies with his father, sees him as a role model." The quotation from A. (37, Ph.D.) shows another important point:

My husband especially meddles in my son's toys. Although I allow him to play with toys he likes regardless of his gender, my husband interferes with worrying "what if his family sees, what if he plays with, for example, dolls also before his family. (A, 37, Ph.D.)

This quotation suggests that although the culture of fatherhood changes (which means, fathers have become more involved), the conduct of fatherhood cannot be thought of as separately from social norms.

Mothers stated that their husbands are more active when they are with their sons than with their daughters and apt to talk to their sons more. For example, W. (42, Ph.D.) said "My husband does not know how to play with our daughter. They think playing house with girls does not befit them." As Zeybekoğlu (2013) points out in her study, given the history of fatherhood, one of the oldest duties of the father is to be the "moral teacher". Similarly, for the female academicians in this study, one of the most crucial 
duties of a father is to teach his son how to be a man. The most repeated statement was "above all, a good father should be a good example."

In short, it can be seen in the father-child relationship in narratives of female academicians that although fathers are now rather playmates of their children, being attentive and fit for the concept of "new father", the understanding that associates fathers with being "the one who provides for and ensures discipline", the traditional father roles, still persists. In this regard, although they are more attentive than traditional fathers, caring for children means nothing more than playing with them. On the other hand, those who bear the responsibility for childcare (school, health, feeding, etc.) are, again, mothers.

Although female academicians with relatively high socioeconomic status and a high educational level are unlikely to adopt a gendered approach in raising their children, their narratives reveal that fathers treat their sons and daughters differently and exhibit fatherhood practices that are in accord with society's notion of masculinity due to the fear of being criticized especially by their families.

\section{Discussion and Conclusion}

When fatherhood is evaluated from a sociological perspective; it is closely related to the way in which society is shaped by the concepts of masculinity and paternity, rather than being biologically male. Fatherhood is influenced by the social structure and forms the structure of the society with the meanings attributed to fatherhood. The process is constructed within the framework of traditional gender roles assigned to women and men in Turkey.

Today's families are experiencing a change but attitudes toward gender roles are determinant, so traditional gender roles maintain their presence. Thus, although fathers are observed to be more involved compared to the past, equal division of labor is not the case.

The younger the children, the greater their emotional needs for their parents. Therefore, paying particular attention to the relationship parents have with their children in the pre-school period will result in a positive impact on a child's psychological development (Öngider, 2013: 437). Traditional gender stereotypes 
consider men the head of household, the master of properties and social life, which renders them authoritarian and oppressive. Since child-related responsibilities are attributed to femininity and motherhood, adoption and maintenance of these roles by men can be perceived as the loss of the status of masculinity. This estranges fathers from the house and childcare. Lack of structural arrangements to facilitate parents' working conditions (free of charge day nurseries, paternity leave, etc.) is related to the understanding that child-rearing and household labor should only be borne by women. Some mothers with whom I interviewed stated that usually, they do tasks related to childcare and housework, although they try to eliminate gender division of labor in the household relationships they establish with their husbands. In this regard, we already mentioned that changing aspects of fatherhood and new fatherhood is problematic for Turkey. However, as Sancar (2009) argues, contrary to the common belief, a new father in Turkey is not an antithesis to conservative masculinity but implies a hybrid form of masculinity. This study also proves this understanding of fatherhood in Turkey. 


\section{References}

Ammari, Tawfiq and Sarita Schoenebeck (2015). "Understanding and supporting fathers and fatherhood on social media sites." In Proceedings of the 33rd Annual ACM Conference on Human Factors in Computing Systems, ACM. 1905-1914.

Atkins, Richard, N. (1981). "Finding one's father: The mother's contribution to early father representations". Journal of the American Academy of Psychoanalysis, 9(4): 539-559.

Bayraktar, Sevi (2011). Makbul Anneler Müstakbel Vatandaşlar. Ankara: Ayizi.

Beşpınar, Fatma Umut (2015). "Between ideals and enactments: The experience of 'New Fatherhood' among middleclass men in Turkey." Gender and Sexuality in Muslim Cultures. In Gül Özyeğin (ed.). Ashgate Publishing, Ltd.. 95-114.

Birer, Biray Anıl (2019). "Kimlik-Mücadele İlişkisi: Feminist Kadınların Anlatılarında Ev İçi Emeğin Bölüşümü”, Kültür ve Iletişim (44): 10-31.

Bjornberg, U. (1992) "Parenting in Transition", European Parents in the 1990s. In U.

Bjornberg (ed.). New Brunswick: Transaction Publishers. 83-103.

Brandth, Berit and Elin Kvande (2018). "Masculinity And Fathering Alone During Parental Leave". Men And Masculinities, 21.1: 72-90.

Booth, Alan and Ann C. Crouter (der.) (1998). Men In Families: When Do They Get Involved? What Difference Does It Make?. New York: Psychology Press.

Bora, Aksu and İlknur Üstün (2005). Sıcak Aile Ortamı-Demokratikleşme Sürecinde Kadın ve Erkekler/Algılar Ve Zihniyet Yapıları: Cinsiyet Rejim Ekseni. İstanbul: TESEV.

Coltrane, Scott (2010). "Gender Theory and Household Labor." Sex Roles, 63(11-12): 791-800.

Connell, Robert W., and James W. Messertschmidt (2005). "Hegemonic Masculinity: Rethinking the Concept." Gender and Society, 19(6): 829-859.

Craig, Lyn (2006). Does Father Care Mean Fathers Share? A Comparison of How Mothers and Fathers Intact Families Spend Time with Children. Gender \& Society, 20: 259-281.

Creswell, John W. (2007). "Five Qualitative Approaches to Inquiry." Qualitative Inquiry And Research Design: Choosing Among Five Approaches, 2: 53-80.

Çağdaş, Aysel (2011). Anne-Baba-Çocuk Iletişimi. Ankara: Kök Yayıncılık. 
Çubuklu, Yaşar (2007). Toplumsal Kurgular Ve Cinsiyetçilik. İstanbul: Everest Yayınları.

Daly, Kerry (1993). "Reshaping Fatherhood: Finding The Models." Journal of Family Issues 14(4): 510-530.

Demez, Gönül. (2005). Degisen Erkeklik Imgesi. Istanbul: Babil.

DeVault, Marjorie and Glenda Gross (2012). "Feminist Qualitative Interviewing: Experience, Talk and Knowledge." The Handbook of Feminist Research Theory and Praxis (2nd ed.). In S. Hesse-Biber (Ed.). Thousand Oaks, USA: Sage. 206236.

Donato, Eliane Maria, et all. (2006). "LC Method for Studies on the Stability of Llopinavir and Ritonavir in Soft Gelatin Capsules." Chromatographia, 63(9-10): 437-443.

Erdoğan, Ayten (2004). "Çocuğun Psiko-Sosyal Gelişiminde Babanın Rolü." Yeni Symposium, 42: 147-153.

Feldman, S. Shirley, Sharon Churnin Nash and Barbara G. Aschenbrenner (1983). "Antecedents of Fathering." Child Development 54: 1628 -1363.

Freeman, Tabitha (2008). "Psychoanalytic Concepts of Fatherhood: Patriarchal

Paradoxes and The Presence Of An Absent Authority." Studies in Gender and Sexuality 9(2): 113-139.

Gillis, John R. (2000). "Marginalization of Fatherhood in Western Countries." Childhood, 7(2): 225-238.

Güngörmüş Özkardeş, Oya (2001). "Baba Çocuk İlişkisi.” Ana Baba Okulu. Haluk Yavuzer (ed) içinde. İstanbul: Remzi Kitabevi.

Gürşimşek, Işık (2002). Etkin Öğrenme ve Aile Katıımı. DEÜ Anaokulu/Anasınıf Öğretmen El Kitabı içinde. İstanbul: YA-PA.

Harris, Kathleen Mullan and S. Philip Morgan. (1991). "Fathers, Sons and Daughters Differential Paternal İnvolvement in Parenting." Journal of Marriage and the Family, 53: 531-544.

Hunter, Sarah C., Damien W. Riggs and Martha Augoustinos (2017). "Hegemonic Masculinity Versus A Caring Masculinity: Implications For Understanding Primary Caregiving Fathers." Social and Personality Psychology Compass, 11.3: e12307. 
İmamoğlu, Olcay E. (1991). Aile İçinde Kadın-Erkek Rolleri. In Türk Aile Ansiklopedisi. Ankara: T.C. Başbakanlık Aile Araştırma Kurumu. 832-35.

Karaköse, Şaban ve Rukiye Karaköse (2007). Çocuk Eğitiminde Babanın Rolü. İstanbul: Yakamoz.

Krampe, Edythe. M. (2009). "When is the Father Really There? A Conceptual Reformulation Of Father Presence." Journal of Family Issues, 30(7): 875-897.

Knauth, Donna G. (2000). "Predictors of Parental Sense of Competence for The Couple During The Transition to Parenthood." Research in Nursing \& Health, 23(6): 496-509.

Kuzucu, Yaşar (2011). "Değişen Babalık Rolü ve Çocuk Gelişimine Etkisi.” Türk Psikolojik Danışma ve Rehberlik Dergisi, 4(35): 79-91.

Lamb, Michael E. (1998). "Fatherhood Then And Now." Men In Families: When Do They Get Involved? What Difference Does It Make?. In Alan Booth and Ann C. Crouter (Eds.) NY: Psychology Press.

LaRossa, Ralph (1988). "Fatherhood and Social Change." Family Relations, 37(4): 451-457. doi:10.2307/584119.

LaRossa, Ralph. (2007). The Culture And Conduct Of Fatherhood in America, 1800 To 1960. Kazoku Syakaigaku Kenkyu, 19(2): 87-98.

Levant, Ronald. F. (1990). "Coping with the New Father Role." Problem Solving Strategies and Interventions For Men in Conflict. In D. Moore and F. Leafgren (Eds.). American Association For Counseling. 81-94.

Mercan, Zerrin and Şahin, F. Tezel. (2017). "Babalık Rolü ve Babalık Rolü Algısı" Uluslararası Erken Çocukluk Eğitimi Çalışmaları Dergisi, 2(2): 1-10.

Mintz, Steven (1998). "From Patriarchy to Androgyny and Other Myths: Placing Mens Family Roles in Historical Perspective." Men in Families. When Do They Get Involved? What Difference Does It Make. In Alan Booth and Ann C. Crouter (Eds.) NY: Psychology Press.

Morgan, David H. (2001). "Family, Gender and Masculinities." The Masculinities Reader. In F. J. Barrett and S. M. Whitehead (Eds.). Cambridge: Polity. 223-232. Öngider, Nilgün (2013). "Anne - Baba ile Okul Öncesi Çocuk Arasındaki İlişki." Psikiyatride Güncel Yaklaşımlar, 5(4): 420 - 440. 
Özdal, Funda and Neriman Aral (2005). "Baba Yoksunu Olan ve Anne-Babası İle Yaşayan Çocukların Kaygı Düzeylerinin İncelenmesi." Gazi Üniversitesi Kırşehir Eğitim Fakültesi Dergisi, 6(2): 255-267.

Petts, Richard J., Kevin M. Shafer and Lee Essig (2018). "Does Adherence To Masculine Norms Shape Fathering Behavior?." Journal of Marriage and Family, 80(3): 704-720.

Ramazanoğlu, Caroline and Janet Holland (2002). Feminist Methodology: Challenges and Choices. London: Sage.

Ranson, Gillian. (2001). "Men at Work: Change-or No Change?-in the Era of the 'New Father'." Men and Masculinities, 4(1): 3-26.

Sancar, Serpil (2009). Erkeklik: Imkansız Iktidar: Ailede, Piyasada ve Sokakta Erkekler. İstanbul: Metis.

Shirani Fiona and Karen Henwood (2011) "Continuity and Change in a Qualitative Longitudinal Study of Fatherhood: Relevance without Responsibility." Intergenerational Journal of Social Research Methodology, 14: 17- 29.

Telli, Ayberk Asena and Hava Özkan (2014). 3-6 Yaş Grubu Çocuğu Olan Babaların Babalık Rolü Algısı Ve Etkileyen Faktörlerin Belirlenmesi. Yayınlanmamış Yüksek Lisans Tezi. Erzurum: Atatürk Üniversitesi Sağlık Bilimleri Enstitüsü Ebelik Anabilim Dalı.

Tezel Şahin, Fatma and Fatma Nilgün Cevher (2007). "Türk Toplumunda Aile - Çocuk İlişkilerine Genel Bir Bakış." ICANAS 38 (38th International Congress of Asian and North African Studies), 775-790.

Tol, Uğraş Ulaş and Demet Taşkan. (2018). Erkeklik ve Babalık Halleri. İstanbul: AÇEV Yayınları.

Yörükoğlu, Atalay (1992). Değişen Toplumda Aile ve Çocuk. İstanbul: Özgür Yayın Dağıtım.

Zeybekoğlu Dündar, Özge, et al. (2011). "Anne ve Baba Sözcüklerine Yüklenilen Anlamların Bir İncelemesi." Contemporary Online Language Education Journal 2: 25-34.

Zeybekoğlu, Özge (2013). "Günümüzde Erkeklerin Gözünden Babalık ve Aile." Mediterranean Journal of Humanities, 3(2): 297-328. 